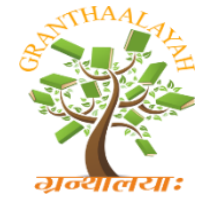

INTERNATIONAL JOURNAL OF RESEARCH GRANTHAALAYAH A knowledge Repository

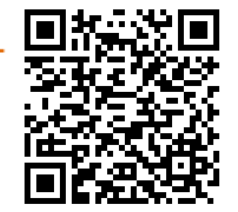

RAST - 17

\title{
STUDY OF DIFFERENT TECHNIQUES TO REDUCE MICROBIAL LOAD IN NUTS
}

\author{
H.T. Sowmya ${ }^{1}$, R.C. Chandni ${ }^{2}$, Amar Sankar ${ }^{3}$, A.V. Raghu ${ }^{4}$ \\ 1, 2, 3,4 Department of Food Technology, Centre for Emerging Technology, Jain University, 562
}

112 , India

DOI: https://doi.org/10.29121/granthaalayah.v5.i4RAST.2017.3313

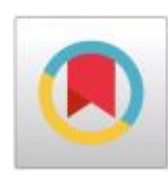

\begin{abstract}
Nuts are very nutritive generally used in food and beverages preparation. In modern perspective, the shelf life extension and its quality is important parameter to be taken in consideration for its processing in food industry. Microbiological and chemical studies have been carried on different batches of received raw nuts stored in woven sack bag contained LDPE bag. For reducing microbial load in nuts four method of treatment was chosen. They are autoclave sterilization, Hot air oven pasteurization, Vacuum oven pasteurization, Microwave oven pasteurization. All four methods temperature kept constant and time is varying. In autoclave sterilization there will be nil microbial count and increasing in all physic-chemical parameters. In vacuum oven pasteurization there will be decreasing in microbial load as the time increasing. And all physic-chemical parameters are coming within specification. In hot air oven pasteurization there will be decreasing in microbial load as the time increasing but sensory and physic-chemical properties of almonds got affected. In micro wave oven sensory parameters of nuts got affected as the time increasing there will be development of roasting flavour and texture of nuts became crunchy.
\end{abstract}

Keywords: Autoclave Sterilization; Physico-Chemical Analysis; Hot Air Pasteurization; Vacuum Oven Pasteurization Acid Value; Peroxide Value.

Cite This Article: H.T. Sowmya, R.C. Chandni, Amar Sankar, and A.V. Raghu. (2017). "STUDY OF DIFFERENT TECHNIQUES TO REDUCE MICROBIAL LOAD IN NUTS." International Journal of Research - Granthaalayah, 5(4) RAST, 122-134. https://doi.org/10.29121/granthaalayah.v5.i4RAST.2017.3313.

\section{Introduction}

Nuts are used in various raw materials in many industries as well as for direct consumption. The relatively high cost of animal protein as well, compared with plant protein in suggest an increasing market for the latter and nuts have attracted interest as a potential source of supplementary protein for human food. There are several products available from the nuts and by its use. They contain an important amount of protein and fat. Due to the extremely high fat, 
[Raghu et. al., Vol.5 (Iss.4: RAST), April, 2017]

ICV (Index Copernicus Value) 2015: 71.21

Recent Advances in Science \& Technology
ISSN- 2350-0530(O), ISSN- 2394-3629(P)

IF: 4.321 (CosmosImpactFactor), 2.532 (I2OR)

InfoBase Index IBI Factor 3.86

protein and low water content it can be easily spoilage by bacteria. Moulds can grow upon them if they stored in improper conditions that can permit sufficient moisture for their growth and propagation. Therefore, this topic was found to be interest, in this study to investigate the microbial contamination of different treated nuts compared with raw nuts. Nuts having longer shelf life (up to 2 years), nutritional parameter of nuts will not change but there will be major changes in flavor, texture, and appearance. The reactions causing these undesirable changes can be very complex. Nuts with kernels are very less prune to microbial contamination because it contains protective layer outside, whereas seeds of nuts are more prone to chances of getting contamination especially yeast and mould. Yeast and moulds is spore forming and can grow at the temperature of $10-50^{\circ} \mathrm{C}$, and growing at lower moisture foods having water activity of $<0.85$. In view of the above discussion and found research gap from literature study following objectives has been decided for this study [6].

\section{Materials and Methods}

\subsection{Autoclave Sterilization}

Autoclave sterilization also called as steam heat sterilization is usually done at $121^{\circ} \mathrm{C}$ for $20 \mathrm{~min}$. But higher the temperature for longer time will affect the texture and sensory attributes of nuts. Reduce the microbial count as well as to retain the sensory attributes four different temperature and time combination have been selected. Keeping temperature constant and varying the time for different minutes like: $121^{\circ} \mathrm{C}$ for $20 \mathrm{~min}, 15 \mathrm{~min}, 10 \mathrm{~min}$ and $5 \mathrm{~min}$ respectively.

Process flow chart of autoclave sterilization

Weigh the nut sample and transfer into retort pouch seal tightly<smiles>CC1CCCC1</smiles>

Place the sample inside the autoclave and close lid

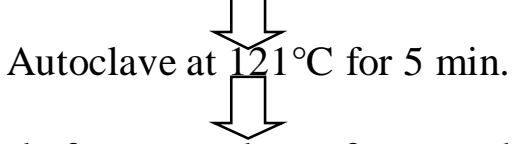

Take out the sample from autoclave after completion of the cycle

\subsection{Vacuum Oven Pasteurization}

Vacuum oven method also called as dry heat pasteurization under vacuum where modified atmosphere will be created inside the oven sterilizing in the absence of air and reducing the microbial activity by $90 \%$ retaining the sensory attributes of the nuts. We choose four time and temperature combination here temperature is constant with varying time like: $90^{\circ} \mathrm{C}$ for $45 \mathrm{~min}$, $30 \mathrm{~min}, 25 \mathrm{~min}$ and $1 \mathrm{hr}$ respectively.

Process flow chart of vacuum oven pasteurization

Clean the inside part of oven by using $70 \%$ of IPA solution

Close the oven properly and tight the valve

Set the air pressure to $100 \mathrm{psi}$ 
Set the temperature up to $90^{\circ} \mathrm{C}$

Simultaneously other sides prepare the sample for keeping

Clean the glass Petri plate by using $70 \%$ IPA solution<smiles>C1CC2CCC1C2</smiles>

Place the sample in Petri plate

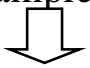

Once temperature reaches to $90^{\circ} \mathrm{C}$ open the door of oven place the sample inside and Close the<smiles>CCC(C)C(C)C(C)C</smiles>

Create the vacuum at $100 \mathrm{psi}$ and note the time<smiles>C1CC2CC3CC1CC23</smiles>

Once treatment get over remove the sample from oven, transfer it in to aluminium pouches seal it tightly

\subsection{Hot Air Oven Pasteurization}

Hot air treatment also called as dry air pasteurization method. In this method samples are treated at different time keeping the temperature constant. The general temperature for hot air oven is $105^{\circ} \mathrm{C}$ for $15 \mathrm{~min}, 25 \mathrm{~min}, 35 \mathrm{~min}$ and $45 \mathrm{~min}$ respectively.

Process flow chart of Hot air oven pasteurization

Switch on oven set the temperature at $105^{\circ} \mathrm{C}$<smiles>CC1CCCC1</smiles>

Take glass Petri plates wipe it with $70 \%$ alcohol<smiles>CC1CC2CC3CC1C23</smiles>

Place the sample in each Petri plate<smiles>CCC(C)C</smiles>

Place the Petri plates inside the oven once it reaches $105^{\circ} \mathrm{C}$<smiles>C1CC2CC3CC1CC3C2</smiles>

Close the door of oven note the exact time<smiles>C1CC2CCC1C2</smiles>

Remove the sample from oven transfer it in to Aluminium pouches seal it tightly

\subsection{Microwave oven method}

Microwave oven method also called as roasting. Roasting will impart flavour development in nuts and also microbial growth reduction. Nuts were treated at different time like 1 min, 2:30 min, 3:30 min and 5 min.

Process Flow Chart of Microwave oven method

Clean the inside microwave oven by using 70\% IPA solution

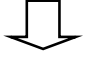

Select four well cleaned Petri plates clean again with $70 \%$ IPA solution

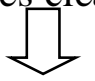


Place nut samples in each Petri plates and transfer the Petri plates inside oven<smiles>C1CC2CCC12</smiles>

Set the time for different minutes

Remove the sample from oven transfer it in to aluminium pouches seal it tightly

\subsection{Microbial Analysis}

\section{Total Plate Count}

\section{Serial Dilution:}

Weigh $10 \mathrm{gm}$ of nut sample grind the nut sample by using pestle and motor. Prepare decimal dilutions of the grinded by transferring $10 \mathrm{gm}$ into $90 \mathrm{ml}$ of pre-sterilized diluents to get the stock solution of $10^{-1}$ dilution. From this test tube, transfer $1 \mathrm{ml}$ of solution into a test tube containing $9 \mathrm{ml}$ of diluents to obtain dilution of $10^{-2}$. Similarly, prepare further dilutions as per requirement.

\section{Pour Plate Technique:}

Raise the petridish lid and add $1 \mathrm{ml}$ of sample to the dish with a micropipette. Touch only the upper half of the sterile pipette when withdrawing it from its wrapper. Draw enough of the sample into the pipette so it is above the volumetric line to be measured. Lower the petridish lid and mix the plate count agar and sample with a gentle circular motion. Do not splash the mixture over the edge of the Petri dish. Allow the media to solidify, then invert the dish and incubate at the $37^{\circ} \mathrm{C}$ temperature.

\section{Yeast and Mould:}

\section{Serial Dilution:}

Weigh $10 \mathrm{gm}$ of nut sample grind the nut sample by using pestle and motor. Prepare decimal dilutions of the grinded by transferring $10 \mathrm{gm}$ into $90 \mathrm{ml}$ of pre-sterilized diluents to get the stock solution of $10^{-1}$ dilution. From this test tube, transfer $1 \mathrm{ml}$ of solution into a test tube containing $9 \mathrm{ml}$ of diluents to obtain dilution of $10^{-2}$. Similarly, prepare further dilutions as per requirement.

\section{Pour Plate Technique:}

Raise the petridish lid and add $1 \mathrm{ml}$ of sample to the dish with a micropipette. Touch only the upper half of the sterile pipette when withdrawing it from its wrapper. Draw enough of the sample into the pipette so it is above the volumetric line to be measured. Lower the petridish lid and mix the CYGA (chlromphenical yeast glucose agar) agar and sample with a gentle circular motion. Do not splash the mixture over the edge of the Petri dish. Allow the media to solidify, then do not invert the dish and incubate at the $25^{\circ} \mathrm{C}$ temperature.

\subsection{Physic-Chemical Analysis}

\section{Moisture}

\section{Procedure}

Initially dry the nickel dish beside its lid in the oven for 30 minutes at $95^{\circ} \mathrm{C}$. Cool it in a desiccators for about 45 minutes and weigh the dish with its lid to the nearest $0.1 \mathrm{mg}$ (M1). 
[Raghu et. al., Vol.5 (Iss.4: RAST), April, 2017]

ICV (Index Copernicus Value) 2015: 71.21

Recent Advances in Science \& Technology
ISSN- 2350-0530(O), ISSN- 2394-3629(P)

IF: 4.321 (CosmosImpactFactor), 2.532 (I2OR)

InfoBase Index IBI Factor 3.86

Transfer the homogenized nut sample into the dish and record the weight with the lid to the nearest $0.1 \mathrm{mg}$ (M2).Place the dish beside its lid into the oven without draught, at ordinary pressure Dry the whole sample for 5hours at $105 \pm 2{ }^{\circ} \mathrm{C}$. Then place the lid onto the dish and let cool to room temperature in desiccators for 45 minutes. Weigh the closed dish to the nearest $0.1 \mathrm{mg}(\mathrm{M} 3)$.

\section{Calculation:}

Moisture content $\%$ by mass $=\underline{\left(\mathrm{M}_{2}-\mathrm{M}_{3}\right) \times 100}$

$$
\mathrm{M}_{2}-\mathrm{M}_{1}
$$

$\mathbf{M}_{1:}$ Mass in grams of the empty dish.

$\mathbf{M}_{2:}$ Mass in grams of the empty dish + Test portion.

$\mathrm{M}_{3}$ : Mass in grams of the empty dish + Test portion after

\section{Water Activity \\ Procedure}

Use the Aqua lab duo on an even level surface under controlled environment temperature. Connect the main power supply \& switch-on the instrument. For best results of measuring high $\mathrm{a}_{\mathrm{w}}\left(>0.9 \mathrm{a}_{\mathrm{w}}\right)$, let Aqua lab duo to warm-up for 15 minutes. Fill the grinded nut sample cup half (do not overfill), Minimum sample amount should cover bottom of the sample cup. Ensure that the rim and outside of sample cup are clean. Ensure that the sample temperature is not more than $4^{\circ} \mathrm{C}$ above the chamber temperature. Place the sample cup in sample chamber. Close lid carefully to avoid spillage. Move latch to the left side to start analyzing the samples. Aqua lab duo gives a beep sound once while starting $\mathrm{a}_{\mathrm{w}}$ measurements. The first $\mathrm{a}_{\mathrm{w}}$ reading will display in a minute or two. Aqua lab duo beeps after the analysis is over. Samples final $\mathrm{a}_{\mathrm{w}}$ reading, temperature and moisture content will be displayed in the provided digital screen.

\section{Acid Value}

\section{Procedure}

Weigh the $50 \mathrm{gm}$ of nuts grind it in to fine powder by using mixer or pestle and motor. Soak the sample in $150 \mathrm{ml}$ of petroleum ether in $250 \mathrm{ml}$ of amber conical flask. Keep it for 24 hours in dark condition_Mix the oil or melted fat thoroughly before weighing. Weigh accurately a suitable quantity (Refer below table) of the cooled oil or fat in a $250 \mathrm{ml}$ conical flask. Add 50ml of freshly neutralized hot ethyl alcohol and $1 \mathrm{ml}$ of phenolphthalein indicator solution._Boil the mixture for about five minutes (till the solution starts boiling) and titrate while as hot as possible against standard aqueous alkali ( $0.1 \mathrm{~N}$ sodium hydroxide) solution, shaking vigorously during titration, till the appearance of pale pink color. The pink color must persist for 30sec. Note down the titer value, when pale pink color appears.

\section{Calculation:}

Acid Value $\quad=\quad$ Titre value $\mathrm{x}$ Normality of alkali $\times 56.1$

Sample weight

FFA $\%$ as Oleic acid $=$ Titre value $\mathrm{x}$ Normality of alkali $\mathrm{x} 28.2$

Sample weight 
[Raghu et. al., Vol.5 (Iss.4: RAST), April, 2017]

ICV (Index Copernicus Value) 2015: 71.21

Recent Advances in Science \& Technology

\section{Peroxide Value}

Procedure

Weigh the $50 \mathrm{gm}$ of nuts make in to fine powder by using mixer. Soak the powdered sample in $150 \mathrm{ml}$ of petroleum ether and mix well. Keep aside for 24 hours in darker condition. Mix the oil or melted fat thoroughly before weighing. Weigh accurately $5 \mathrm{~g}$ of the cooled oil or fat in a 250 $\mathrm{ml}$ iodine flask. Add $30 \mathrm{ml}$ of Solvent mixture \& mix well. Add $1 \mathrm{ml}$ of freshly prepared, saturated potassium iodide solution. Stopper the flask immediately and swirl to dissolve. Keep the flask in dark for 2 minutes with occasional shaking. After that, add $50 \mathrm{ml}$ of distilled water to the flask. [Part of the water is used for the rinsing of the stopper and the washings are also transferred into the flask]. Using Starch indicator solution, titrate the contents of the flask against $0.02 \mathrm{~N}$ sodium thiosulphate [hypo] with vigorous shaking solution till the disappearance of blue colour. Carry out the experiment in duplicates for better interpretation of results and Note down the titre value. Carry out/conduct a blank determination and Note down the titre value.

Calculation:
Peroxide value $(\mathrm{meq} / \mathrm{kg})=(\underline{\mathrm{T}-\mathrm{B}) \times \mathrm{N} \times 1000}$
$\mathrm{W}$
Where,
$\mathrm{T}=$ Sample Titre Value (Volume in millilitres of $0.02 \mathrm{~N}$ sodium thiosulphate consumed by sample $)$
$\mathrm{B}=\mathrm{Black}$ Titre value.
$\mathrm{W}=$ weight in gram of sample taken.
$\mathrm{N}=$ normality of sodium thiosulfate solution.

\section{Result and Discussion}

The main motto is to reduce microbial load as well as retain sensory attributes and quality parameters. Firstly we did steam sterilization by autoclave in different timings here temperature is constant i.e. $5 \mathrm{~min}, 10 \mathrm{~min}, 15 \mathrm{~min}, 20 \mathrm{~min}$, for doing sterilization we packed almonds in retort pouches and sealed tightly. Retort pouch which is act as good barrier against heat and steam. After sterilization we did microbial analysis we kept in observation for five days for results, after five days of results we concluded that there is no growth in all four trails, but there is some changes in quality attributes and also in sensory attributes. In quality parameter water activity, moisture and non-volatile ether extract got increased this is due to steam absorption by almonds during sterilization, due to that almonds absorbed some extra moisture during sterilization this leads to increase in water activity, moisture, and non-volatile ether extract. Among four trails we selected one trail which is having less microbial growth and less water activity, moisture and non-volatile ether extract for sensory evaluation. Secondly we have chosen vacuum oven method where vacuum is applied at different pressure that is at 100 psi and 200 psi at same temperature for different timings i.e. $45 \mathrm{~min}, 30 \mathrm{~min}, 25 \mathrm{~min}, 1$ hour. In that we did microbial analysis for all four samples, we kept observation for 5 days. After five days we took microbial count for all samples. We chose one sample from all four then conducted sensory for selected sample. 
Table 1: Various process parameters and autoclave sterilization

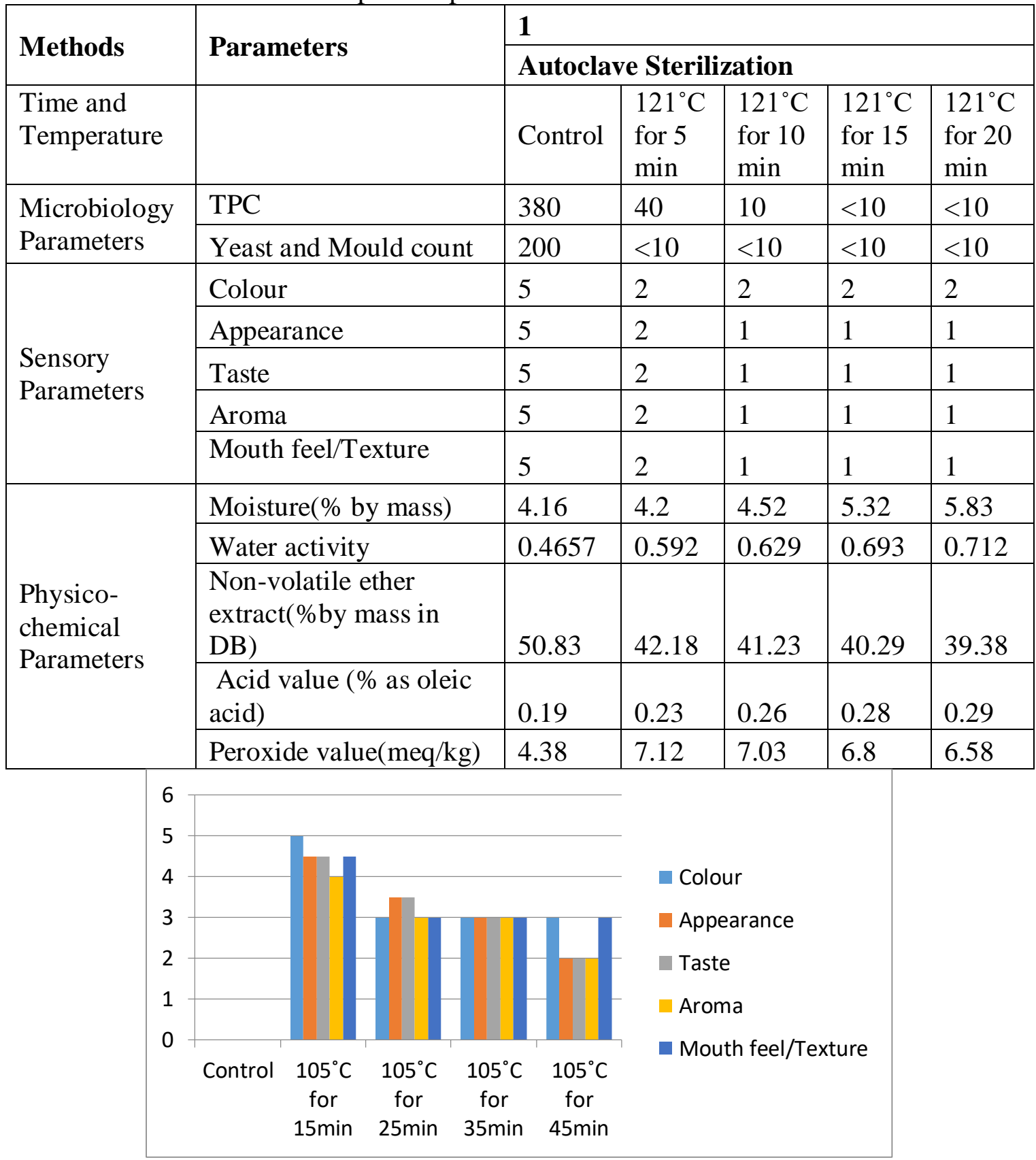

Table 2: Various process parameters and vacuum oven sterilization

\begin{tabular}{|l|l|l|l|l|l|l|}
\hline \multirow{2}{*}{ Methods } & \multirow{4}{*}{ Parameters } & \multicolumn{3}{|l|}{$\mathbf{2}$} \\
\cline { 3 - 8 } & & Vacuum oven sterilization \\
\hline $\begin{array}{l}\text { Time and } \\
\text { Temperature }\end{array}$ & & Control & $\begin{array}{l}90^{\circ} \mathrm{C} \\
\text { for 25 } \\
\text { min }\end{array}$ & $\begin{array}{l}90^{\circ} \mathrm{C} \\
\text { for 30 } \\
\text { min }\end{array}$ & $\begin{array}{l}90^{\circ} \mathrm{C} \\
\text { for } 45 \\
\text { min }\end{array}$ & $\begin{array}{l}90^{\circ} \mathrm{C} \\
\text { for 1 } \\
\text { hour }\end{array}$ \\
\hline Microbiology & TPC & 450 & 150 & 100 & 60 & 30 \\
\hline
\end{tabular}




\begin{tabular}{|c|c|c|c|c|c|c|}
\hline Parameters & YM & 230 & 90 & 70 & 30 & 10 \\
\hline \multirow{5}{*}{$\begin{array}{l}\text { Sensory } \\
\text { Parameters }\end{array}$} & Colour & 5 & 4.5 & 4 & 4 & 3 \\
\hline & Appearance & 4.5 & 4 & 4 & 4 & 3.5 \\
\hline & Taste & 4 & 4 & 4 & 4 & 3 \\
\hline & Aroma & 4 & 4 & 4 & 4 & 3 \\
\hline & Mouth feel/Texture & 4 & 4 & 4 & 4 & 3 \\
\hline \multirow{4}{*}{$\begin{array}{l}\text { Physico- } \\
\text { chemical } \\
\text { Parameters }\end{array}$} & Moisture( $\%$ by mass) & 4.2 & 3.25 & 3.39 & 2.84 & 2.35 \\
\hline & Water activity & 0.4645 & 0.4362 & 0.4385 & 0.4232 & 0.4201 \\
\hline & $\begin{array}{l}\text { Non-volatile etherextract }(\% \text { by } \\
\text { mass in DB) }\end{array}$ & 53.23 & 36.48 & 37.12 & 39.1 & 40.08 \\
\hline & Acid value (\% as oleic acid) & 0.18 & 0.16 & 0.16 & 0.17 & 0.19 \\
\hline
\end{tabular}

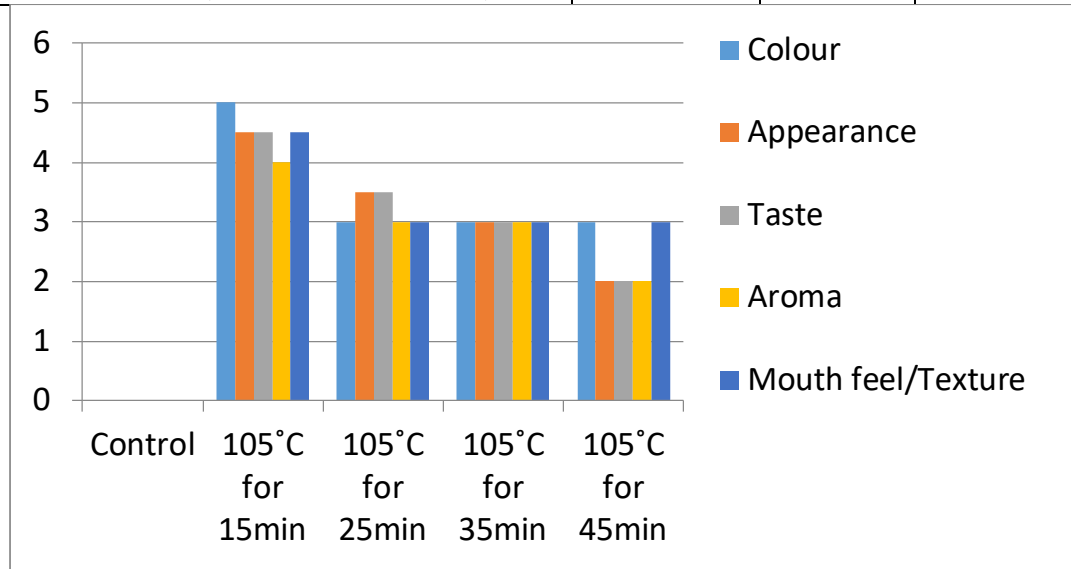

In vacuum oven method we observe that moisture got decreased slightly compared to the control. And also water activity got decreased slightly. Peroxide value and acid value is not varied much the readings are within specification. Moisture and water activity decreased due to moisture loss during heat treatment $90^{\circ} \mathrm{c}$ is the higher temperature where moisture can evaporate up to certain level. After treatment the sample took for moisture analysis already some of the moisture loss during heat treatment again for moisture sample kept in oven for 5 hours so again sample dried to bone dry condition.

After microbial analysis and sensory evaluation we observed gradual difference in microbial load in each sample after counting colonies of each different trail we have selected one trail from each method which is having less microbial growth as well as more score in sensory evaluation. We did analysis for choose sample again and conducted the sensory analysis.

Third method we have chosen is hot air oven method in which almonds are treated at same temperature for different timings. i.e. $105^{\circ} \mathrm{C}$ for $15,25,35,45 \mathrm{~min}$. After treatment all four samples are did microbial analysis. After that all four samples are kept under 5 day's observation. 
Table 3: Various process parameters and hot air oven sterilization

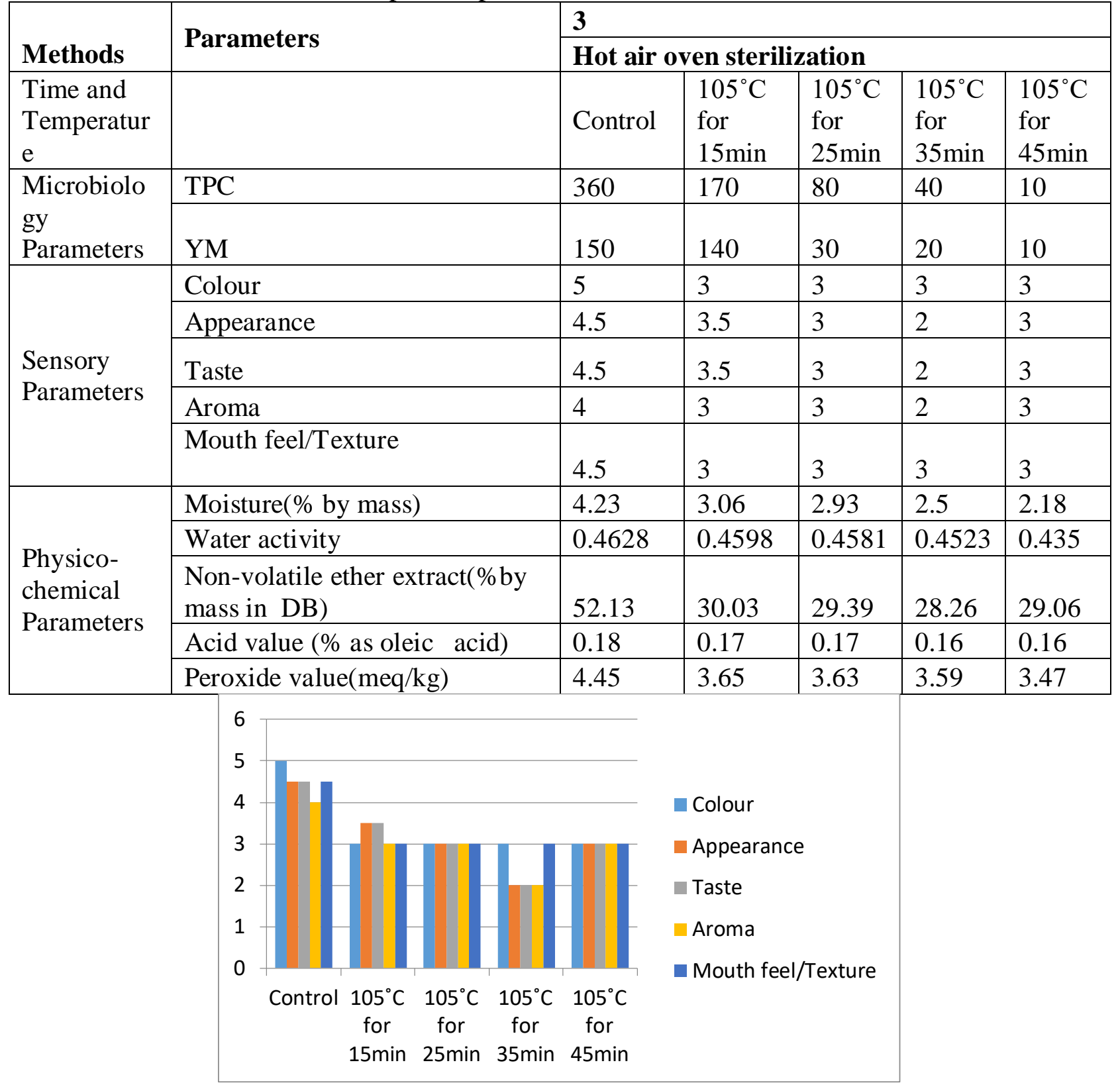

Table 4: Various process parameters and microwave oven sterilization

\begin{tabular}{|c|c|c|c|c|c|c|}
\hline \multirow{2}{*}{ Methods } & \multirow{2}{*}{ parameters } & \multicolumn{5}{|l|}{4} \\
\hline & & \multicolumn{5}{|c|}{ Microwave oven } \\
\hline $\begin{array}{l}\text { Time and } \\
\text { Temperature }\end{array}$ & & control & $1 \mathrm{~min}$ & $2 \mathrm{~min}$ & $\begin{array}{l}3: 30 \\
\min \end{array}$ & $5 \mathrm{~min}$ \\
\hline \multirow{2}{*}{$\begin{array}{l}\text { Microbiology } \\
\text { Parameters }\end{array}$} & $\mathrm{TPC}$ & 480 & 300 & 200 & 70 & 50 \\
\hline & YM & 250 & 150 & 90 & 40 & 20 \\
\hline Sensory & Colour & 4.5 & 3 & 2 & 2 & 2 \\
\hline
\end{tabular}


Recent Advances in Science \& Technology

InfoBase Index IB I Factor 3.86

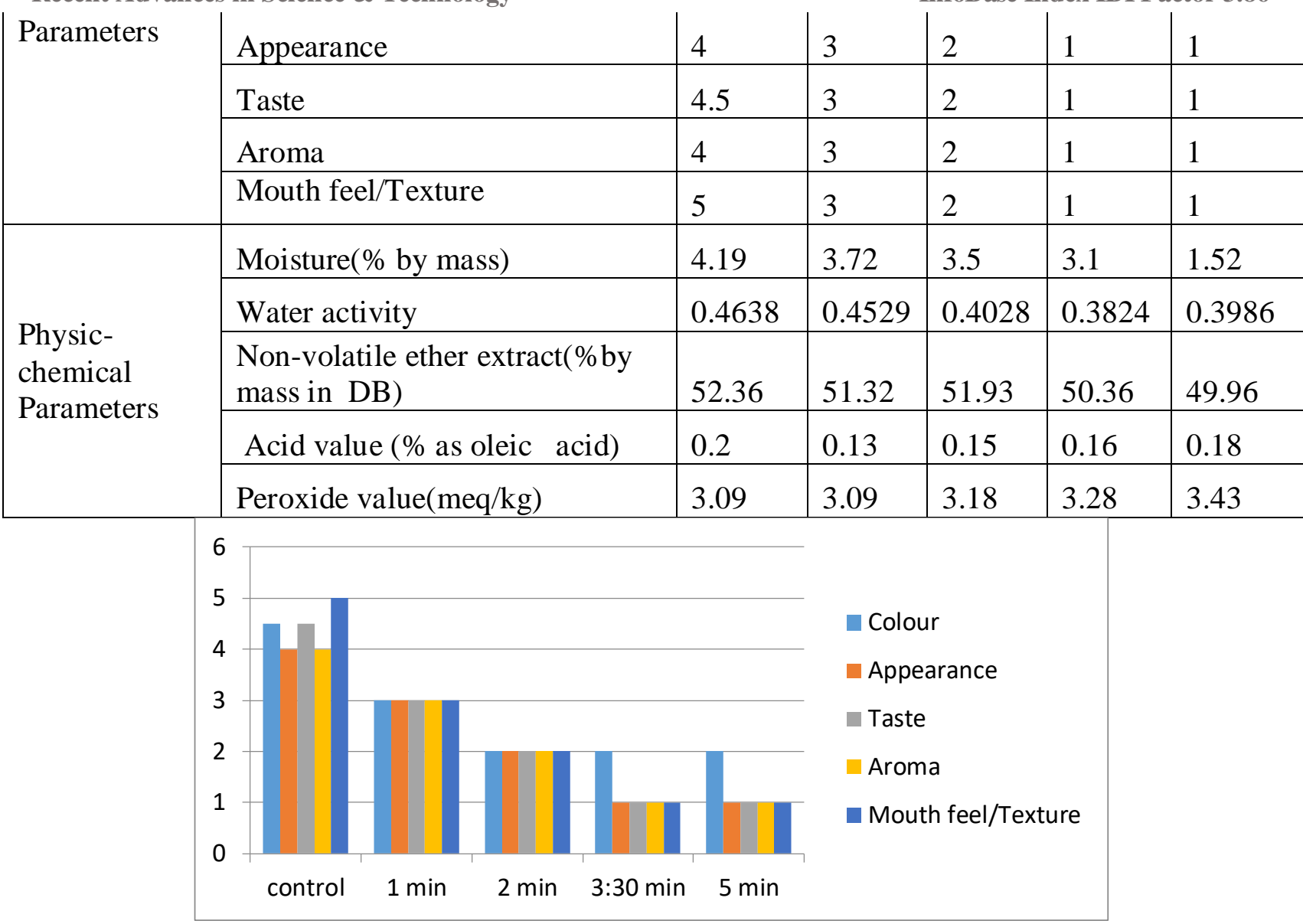

In hot air oven method we observe that there is decrease in moisture content and water activity due to moisture loss during heat treatment whereas non-volatile ether extract and peroxide value, acid value meeting specification. Fourth method we have chosen is micro wave oven treatment in that method samples are treated to different timings in heat treatment mode respective timings are $1 \mathrm{~min}, 2 \mathrm{~min}, 3: 30 \mathrm{~min}$, and $5 \mathrm{~min}$. After heat treatment all four samples are analysed for microbial analysis. All four samples kept under observation for 5 days then we have chosen one sample which is having low microbial count and good sensory attributes. The five min treated sample is having low microbial count but in sensory wise it get roasted more. Loses all sensory parameters. In physic chemical parameters moisture and water activity got decreased all other parameters are meeting specification.

In the part of sensory analysis one product is accepted based on the rating. Sensory analysis is conducted by 5 semi trained panels. Duo trio test was conducted it means four selected samples kept for sensory analysis including control among three samples the sample which is having similar taste to control was to be identified and ratings has to give based on that. Based on the ratings mean should be calculated for each sample and the sample which is having higher mean should be finalised. In the final result of sensory analysis we finalised vacuum oven for $90^{\circ} \mathrm{c}$ for $45 \mathrm{~min}$. This is meeting all sensory attributes of control sample. The rating given by all 5 sensory panels for this sample is 4 which mean sample is good. There will be five ratings given for all four samples, ratings given by number each number is having different description i.e. 5 means very good 4 means good 3 means 2 means 1 means poor. Based on considering different ratings 
given by 5 semi trained panel, vacuum oven $\left(90^{\circ} \mathrm{C}\right.$ for $\left.45 \mathrm{~min}\right)$ has been finalised. This is meeting all quality attributes and also having similar sensory parameters of control.

\section{Sensory Analysis}

Table 5: Sensory evaluation parameters and panels score

\begin{tabular}{|l|l|l|l|l|l|l|}
\hline S.No. & $\begin{array}{l}\text { Product } \\
\text { Parameter }\end{array}$ & $\begin{array}{l}\text { Hot air } \\
\text { sterilized } \\
\text { almond } \\
\mathbf{1 0 5}^{\circ} \mathbf{C} \text { for } \\
\mathbf{3 5 m i n}\end{array}$ & $\begin{array}{l}\text { Vacuum } \\
\text { oven } \\
\text { sterilized } \\
\text { almond } \\
\mathbf{9 0} \mathbf{C} \text { Cor } \\
\mathbf{4 5} \text { min }\end{array}$ & $\begin{array}{l}\text { Micro } \\
\text { wave oven } \\
\text { sterilized } \\
\text { almond } \\
\mathbf{3 : 3 0 ~} \text { min }\end{array}$ & $\begin{array}{l}\text { Autoclave } \\
\text { sterilized } \\
\text { almond } \\
\mathbf{1 2 1} \mathbf{C}_{\text {for }} \mathbf{5} \\
\text { min }\end{array}$ & Control \\
\hline 1 & Colour & 3.4 & 3.8 & 2 & 2 & 4 \\
\hline 2 & Appearance & 3.4 & 3.8 & 1 & 2 & 4 \\
\hline 3 & Taste & 3.6 & 3.5 & 1 & 2 & 4 \\
\hline 4 & Aroma & 3.4 & 3.8 & 1 & 2 & 4 \\
\hline 5 & Mouthfeel/Texture & 3.2 & 3.7 & 1 & 2 & 4 \\
\hline 6 & $\begin{array}{l}\text { Overall } \\
\text { Acceptability }\end{array}$ & 3.2 & 3.7 & 2 & 2 & 4 \\
\hline
\end{tabular}

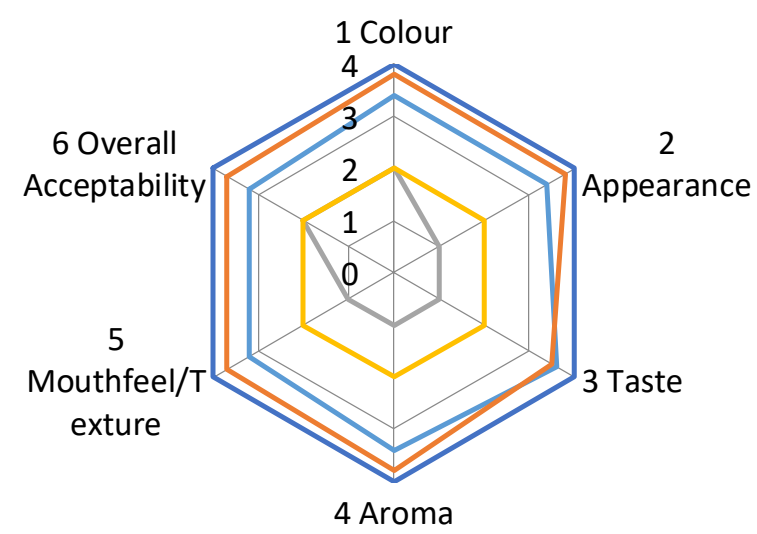

Hot air sterilized almond $105^{\circ} \mathrm{c}$ for $35 \mathrm{~min}$

Vacuum oven sterilized almond $90^{\circ} \mathrm{C}$ for $45 \mathrm{~min}$

Micro wave oven sterilized almond 3:30 $\min$

Autoclave sterilized almond $121^{\circ} \mathrm{c}$ for $5 \mathrm{~min}$

\section{Conclusions}

Vacuum oven method is best for controlling microbial load and to minimise sensory attributes of nuts. From all four methods we finalised vacuum oven method $\left(90^{\circ} \mathrm{c}\right.$ for $\left.45 \mathrm{~min}\right)$. In this method colour of sample and texture of sample is same as like control sample. Microbial result also came within specification. Finally vacuum oven sterilization suggested for preventing microbial load in nuts. After sterilization proper storage and packaging is necessary to prevent contamination from surrounding. If proper package is not done again re contamination of nuts may happen. 


\section{Acknowledgements}

We thank the Ministry of Food Processing and Industries, (MOFPI), Government of India for the award of Food Technology Centre, CET, Jain University.

\section{References}

[1] Nut Board of California. 2007. Guidelines for validation of dry roasting processes, v1.2.

[2] http://www.nutboard.com/Handlers/Documents/Dry-Roast-Validation-Guidelines.pdf, accessed on 8 July, 2017

[3] Nut pasteurization, the food safety system. March 30, 2009.

[4] Nut Board of California, July 2014. Nut shelf life factors, page no 1-4

[5] Amany Ahmed Niazy. CLS 311: Basic Microbiology, Inhibiting Microbial Growth in vitro.

[6] Australian nuts.com.au/trade/Australian-nuts-health-nutrition, accessed on 8 July, 2017

[7] Bari L, Nei D, Sotome I, Nishina IY, Hayakawa F, Isobe S, Kawamoto S. 2010. Effectiveness of superheated steam and gas catalytic infrared heat treatments to inactivate Salmonella on raw nuts. Foodborne Patog Dis 7:845-50.

[8] Chang SS, Han A, Reyes-De-Corcuera J, Powers J, Kang DH. 2010. Evaluation of steam pasteurization in controlling Salmonella serotype Enteritidis on raw nut surfaces. Lett Appl Microbiol 50:393-8.

[9] Cuervo MP. 2011. Comparison of current nut pasteurization methods and electron beam irradiation as an alternative. [DPhil dissertation]. College Station, TX: Texas A\&M Univ. Available from: Texas A\&M University Repository.

[10] Danyluk M, Jones TM, Abd SJ, Schlitt-Dittrich F, Jacobs M, Harris LJ. 2007a. Prevalence and amounts of Salmonella found on raw California nuts. J Food Prot 70:820-7.

[11] Danyluk MD, Harris LJ, Sperber WH. 2007b. Nuts and cereals. In: Doyle MP and Beuchat LR, editors. Food Microbiology: Fundamentals and frontiers. Washington, D.C.: American Society for Microbiology Press. p 171-83.

[12] Du, W.-X., S. J. Abd, K. L. McCarthy, and L. J. Harris. 2010. Reduction of Salmonella on inoculated nuts exposed to hot oil. J Food Prot 73:1238-1246.

[13] E. M. Darmady, K. E. A. Hughes, J. D. Jones, D. Prince, and Winifred Tuke., Sterilization By Dry Heat. May 27, 2017.

[14] Federal Register. 2007. Nuts grown in California; outgoing quality control requirements. Fed. Reg. 72:15021-15036.

[15] http://www.gpoaccess.gov/fr/retrieve.html, accessed on 8 July, 2017

[16] Goodridge, L. D., J. Willford, and N. Kalchayanand. 2006. Destruction of Salmonella Enteritidisinoculated onto raw nuts by high hydrostatic pressure. Food Res. Int. 39:408-412.

[17] Guidance for validation of blanching process. April 2007.

[18] Harris, L.J., A.R. Uesugi, S.J. Abd, and K. L. McCarthy. 2011. Survival of Salmonella Enteritidis PT 30 on inoculated nut kernels in hot water treatments. Food Res. Int. 45:1093-1098.

[19] [19]. Perren, R., F.E. Escher. 2013. Impact of roasting on nut quality, pp. 173-197. In L.J. Harris(ed.), Improving the safety and quality of nuts. Woodhead Publishing Ltd., Cambridge, UK.

[20] Prue McMichael, Scholefield Robinson, What threatens the safety of Nuts? Nov 12.

[21] USDA National Nutrient Database for Standard Reference website: http://www.nal.usda.gov/fnic/foodcomp/search/, accessed on 8 July, 2017

[22] USDA SR25 Nutrient Database No. 12061 Nuts, nuts, natural.

[23] Yashmin Sultana, Pharmaceutical Microbiology and Biotechnology Sterilization Methods and Principles. 
[Raghu et. al., Vol.5 (Iss.4: RAST), April, 2017]

ICV (Index Copernicus Value) 2015: 71.21

Recent Advances in Science \& Technology
ISSN- 2350-0530(O), ISSN- 2394-3629(P)

IF: 4.321 (CosmosImpactFactor), 2.532 (I2OR)

InfoBase Index IBI Factor 3.86

[24] Young, C.T., W.E. Schadel, H.E. Pattee, T.H. Sanders. 2004. The microstructure of nut (Prunus dulcis (Mill.) D.A. Webb cv. 'Nonpareil') cotyledon. LWT - Food Science and Technology 37(3):317-322.

[25] Zahra Hassan Mohammad, effect of accelerated drying on the reduction of salmonella on nuts by thermal and electron beam irradiation pasteurization treatment. 2013

[26] Zhongli pan, Gokhanbingol, Maria, T. Brandl. Tara H. MC Hugh, Review of current technologies for reduction of salmonella populations on nuts. 2012.

*Corresponding author.

E-mail address: gsraghu2003@yahoo.co.in 